This is the version of the article accepted for publication in Asia Europe Journal published by Springer https://doi.org/10.1007/s10308-018-0513-X

Accepted version downloaded from SOAS Research Online: http://eprints.soas.ac.uk/25703

\title{
China's Silk Road Economic Belt Initiative in Central Asia: Economic and Security Implications
}

\author{
Bhavna Dave and Yuka Kobayashi (SOAS, University of London) ${ }^{1}$
}

\begin{abstract}
The Silk Road Economic Belt (SREB) initiative, launched by Xi Jinping in 2013 as the Central Asian component of the Eurasian Belt and Road Initiative (BRI), is presented as a trade and infrastructural developmental initiative that benefits all to deliver stability. It consolidates Beijing's existing economic investments and security-building measures, while launching new projects to link the regions of Central Asia and South Asia more closely with China and extend the arc of security westward and develop these as a transport corridor linking China to Europe.
\end{abstract}

This article examines the interaction between China's infrastructural investments and security dynamics in the Central Asian region, exploring why the BRI/SREB, presented by China as primarily as a developmental vision, is fraught with wide-ranging security implications. We examine the reception of China's BRI/SREB in Central Asia focusing on the following three dimensions: 1) the lure of Chinese investments which makes SREB particularly attractive for Central Asian countries; 2) the securitization thrust of the Silk Road initiative which consolidates the power of the Central Asian regimes but also grants considerable role to China in managing security arrangements; 3) elite manoeuvring between the lure of Chinese investments and appeasing popular anxieties about China's growing influence.

It points to the overall positive reception in the region to the aid and investment offered by China, while noting the variance in their responses based on the implications of SREB for their sovereignty and security and also concerns on whether the promised benefits of connectivity and development (a "win-win" scenario) will materialize. The article concludes by outlining the implications of China's rising economic and security engagement in Central Asia and the close Sino-Russian partnership for European financial and security interests and highlights the areas of cooperation and complementarity between China and EU in the region.

\footnotetext{
${ }^{1}$ bd4@soas.ac.uk and yk37@soas.ac.uk.

The authors would like to acknowledge Peter Morton for his editorial assistance.
} 


\section{Introduction}

The Central Asian region, sharing ethnocultural and religious commonality and territorial contiguity with the restive region of Xinjiang across the border as well as trade and commercial ties, has occupied a crucial position in China's foreign policy. The intensive industrial development of Xinjiang undertaken by Beijing to dispel separatist sentiments, its growing economic and commercial partnership with the Central Asian region since 1990s, and the formation of the Shanghai Cooperation Organization (SCO) have enabled China to muster increasing economic and political influence and extend the arc of security westward into Central Asia and onwards to Afghanistan. The Silk Road Economic Belt (SREB) initiative, which is the Central Asian component of the global Belt and Road Initiative (BRI) launched by Xi Jinping in 2013, consolidates Beijing's existing economic investments and security-building measures, while launching new projects to link the regions of Central Asia and South Asia, more closely with China and develop these as a transport corridor linking China to Europe.

The BRI, or yi dai yi lu in Chinese, is comprised of the SREB and the Maritime Silk Road (MSR). The English translation of yi dai yi lu has undergone three changes: Silk Road Economic Belt (used in Xi's Astana speech) in September 2013, One Belt One Road (OBOR) in 2014, and Belt and Road Initiative in 2015 (Xi 2013, Xi 2014, NDRC 2015). Presented as a vision of development which is consistent with Chinese traditional culture emphasizing a harmonious and secure environment with its neighbours, the BRI builds on China's growing military and economic stature, particularly its rapid economic development after WTO accession in 2001. The BRI is supported by Xi's earlier ideals, the "China Dream" and "two centuries projects", which projects a militarily and economically strong China taking it into its centenary of establishment (Callahan 2016). China's rapid rise has offered both a 'material' and an 'ideational' basis for its leadership to promote its grand ideas of connectivity in infrastructure on a global scale combing its investments/financing with the notions of development and prosperity enhancing security.

There has been much debate in the preceding decade whether China has had a 'strategy' in Central Asia: Kerr (2010) sees Chinese policies as advancing a "strategic regionalism" in Central Asia, whereas Zhao (2007) sees the CCP strategy as more ad hoc and lacking strategic coherence. The SREB, unveiled in 2013, brings together China's bilateral, regional and multilateral infrastructure projects, their financing/investments in the region under one umbrella as part of its BRI. Central to the BRI are the economic corridors, which bring these rail, road connections via a series of transport nodes that are strategically places on land (Belt) and sea (Road), in harmony with Chinese ideals of economic and social development and in strategically important locations for Chinese security. Presented by China as primarily as a trade and infrastructural developmental initiative, the BRI/SREB is fraught with wideranging security implications, which extend to Afghanistan as well as the adjacent territories of China-Pakistan Economic Corridor. ${ }^{2}$ Particularly significant in enhancing the security implications of the BRI are: 1) the close Russia-China partnership in the region in the face of the declining influence of the West; 2) the close development-security nexus in China's thinking as articulated in the BRI; 3) the massive infrastructural investments made by China to enhance connectivity between China through Xinjiang, the landlocked Central Asian

\footnotetext{
${ }^{2}$ China's developmental goals in the BRI and "China Dream" have both economic and security elements; however, the externally projected BRI is primarily an economic/development initiative with "win-win" solutions for the countries involved (Xi 2014, 2016).
} 
region, passing through South and West Asia onwards with Europe and other regions, and the ensuing engagement in security provisions to safeguard these projects and promote stability in the region.

The article addresses the above-mentioned factors as it examines the less-studied dimension of interaction between China's infrastructural investments and security dynamics - a central tenet of the BRI and the Silk Road initiative - in the broader Central Asian region. The official statements and rhetoric underscore the role of Central Asia as a valued neighbour and an equal beneficiary of the development, and as a region where China desires to extend its arc of security and turn it into a secure trade and transport corridor linking it with Europe. The term 'greater Central Asia', popularised by the US in post 9 September 2011 context includes not only the five post-Soviet states of Central Asia-Kazakhstan, Kyrgyzstan, Tajikistan, Uzbekistan and Turkmenistan-but also the Chinese province of Xinjiang, Afghanistan, and the adjacent regions of Iran, northern parts of Pakistan as well as the regions bordering India (Starr 2005; Clarke 2013). This broad definition of Central Asia syncs well with the Eurasian focus of the BRI. More recently, the term 'greater Eurasia' (bol'shaya Evraziia) has been promoted in geo-strategic thinking in Russia as an expansive notion to include the former Soviet territories, China, Afghanistan and neighbouring friendly regions including Iran and India (SPIEF 2017). China has also endorsed the use of the term which allows the country and the SCO to acquire a broader Eurasian profile.

Taking this broad definition of Central Asia, we examine the reception of China's BRI/SREB in Central Asia focusing on the following three dimensions: 1) the lure of Chinese investments which makes SREB particularly attractive for Central Asian countries), 2) the securitization thrust of the Silk Road initiative which consolidates the power of the Central Asian regimes but also grants considerable role to China in managing security arrangements; 3) Elite manoeuvring between the lure of Chinese investments and appeasing popular anxieties about China's growing influence.

The article points to the overall positive reception in the region to the aid and investment offered by China, while noting the variance in their responses based on the implications of SREB for their sovereignty and security and also concerns on whether the promised benefits of connectivity and development (a "win-win" scenario) will materialise. Notwithstanding its pledges of non-interference in domestic affairs and disavowal of forming any military alliances, China is increasingly becoming drawn into assuming security provision functions through cooperation with national governments on enhancing border security, counterterrorism measures, and aiding a modernization of defense and military equipment which are also aimed at protecting Chinese projects, investments and personnel.

In conclusion, the article outlines the implications of China's rising economic and security engagement, and the strengthening Sino-Russian partnership for European financial and security interests in the region. The article draws on a number of visits by Dave and Kobayashi during 2015-17 to Central Asia/Russia and China/Europe respectively and discussions with scholars, analysts and practitioners. In addition, participant observation and qualitative semi-structured interviews were conducted with key individuals involved in the BRI in Central Asia, China and Europe. ${ }^{3}$

${ }^{3}$ Where available, primary and secondary sources were used to triangulate the findings from fieldwork. 


\section{Central Asian Responses to the Silk Road Economic Belt}

The Silk Road has been "one prominent metaphor used to depict Xinjiang's intermediate position between China, Central Asia and beyond" (Millward 2009). However, in contrast to the medieval silk routes in which the vast Central Asian region together with Xinjiang formed the key nodes, the SREB is decidedly Sino-centric - a central objective being the creation of incentives and outlets for the less developed Xinjiang as gateway for new transport and trade corridors via Central Asia to markets and exports routes in Europe and beyond. $^{4}$

Two of the key or game-changing projects connecting Xinjiang with Central and South Asia which have now been encompassed under the BRI/SREB are: 1) Khorgos free economic zone along the China-Kazakhstan border where the city of Khorgos is envisioned as the biggest 'dry port' to provide access for Chinese goods to markets in the Middle East, Europe and Africa; and 2) the China Pakistan Economic Corridor (CPEC), which begins in Kashgar in Xinjiang, going southward to Pakistan, intersecting with border regions in Tajikistan and parts of India-Pakistan border, and ending in the China-built Gwadar port on the Arabian sea.

As noted above, all five Central Asian states and Russia have officially welcomed the SREB initiative, and sought to align their own developmental agendas, priorities and political objectives with it. The prospects of transport connectivity, greater opportunities for trade and earning transit fees as well as development and export of their natural resources are very attractive to all states in the region. China's quest for land connectivity to Europe and greater access to its market rest heavily on its ability to succeed in Central Asia, and in particular, Kazakhstan, the $9^{\text {th }}$ largest state spread over the enormous Eurasian expanses. Kazakhstan is not only of geopolitical importance but also a significant supplier of energy resources to China. At least $20 \%$ of investments in its oil production is by China (Tengri News 2013).

Embracing the Initiative, Nazarbaev pledged an investment of $\$ 9$ billion in the development of its railroad sector and other infrastructural projects to support SREB and the Khorgos Free Economic Zone on the Kazakhstan-China border. ${ }^{5} \mathrm{He}$ followed this up by presenting a modified version of the national strategy, "Nurly Zhol" ("Bright Path"), emphasizing the "complementarity" (sostykovka) between SREB and Nurly Zhol developmental strategies. Kazakhstani analysts have noted the importance of Kazakhstan as the "buckle" (pryazhka) holding the Belt, highlighting its position as a potential gateway to the Caspian Sea and on to Europe, whose "future economic growth depends heavily on transport infrastructure and regional trade" (Chikanaev 2017).

Uzbekistan and Turkmenistan have been more circumspect in opening up their economies to foreign investment though they have already established close bilateral cooperation in railroad and pipeline construction financed by China; the former closely cooperates in Chinainitiated securitization policies geared at combating terrorism (the Regional Anti-Terror Structure, RATS headquarters are located in Tashkent). Though it has elevated "neutrality" as its foreign policy doctrine (it has neither joined SCO nor officially issued a statement on SREB), Turkmenistan has cultivated a close bilateral cooperation with China with the construction of Central Asia-China pipeline network which has facilitated the delivery of its gas to China with a number of lines passing through Uzbekistan, Tajikistan and Kyrgyzstan.

\footnotetext{
${ }^{4}$ These Chinese ideals are found policies such as Zhu Rongji's "Develop the West" Initiative predating the BRI. The importance of Xinjiang is evident in details of the CPEC (Hussain 2017).

${ }^{5}$ The Khorgos dry port was formally launched in 2011 although construction predates this.
} 
The developmental thrust of SREB and "win-win" promise are very appealing to Kyrgyzstan and Tajikistan, dependent on Russia's military and security assistance.

\section{Chinese developmental promise and financing}

China has established a reputation and niche in financing and building massive infrastructural development projects at a rapid pace and a low cost, particularly in Africa, and engaging in the same in Central Asia, South and South East Asia, Latin America and Europe (Kobayashi and Sanchez 2017). It has not shied away from investing in regions seen as too unstable and presenting investment risks, signified by its welcome by the 65 countries (as of October 2017) participating in the BRI (SIC 2017). With Western investors being wary of investing in Central Asian states which lack governance capacity and effective rule of law (Kazakhstan being an exception) and Russia prioritizing military and security-linked aid, China has been providing financial and technical assistance, refurbishing old links and initiating new projects in the region filling in the "\$8 trillion infrastructural funding gap" (ADB 2012). The motto of stability and "development for all" (or "win-win") in the Chinese economic model makes it very attractive to local elites lacking alternative sources of financing. Unlike Western states, China is able to deliver financing quickly, without the lengthy process of detailed feasibility and socio-political and environmental effects of investments. China has been filling the gaps in the existing transport and energy supply routes for Kyrgyzstan and Tajikistan, both landlocked mountainous states. China has become the largest foreign investor in both, and in turn assuming greater security provision functions, which are fraught with uncertain economic and political consequences.

China's investments in Kyrgyzstan's transport and electricity supply grid and refurbishment of power lines have helped to connect its northern and southern regions separated by mountains. President Almazbek Atambayev hailed these projects for finally establishing his country's "energy independence" in 2015, after years of having been beholden to Uzbekistan with whom it has had strained relationship for many years (Eurasianet 2015). The direct energy links allow it to save \$8-9 million annually in transit fees paid to Uzbekistan (Putz 2015).

The China-Kyrgyzstan-Uzbekistan railway construction, estimated to cost $\$ 5$ to 6 billion, is one of the most ambitious and technologically challenging projects passing through the highaltitude mountainous terrain of western China and Kyrgyzstan with 50 tunnels and more than 90 bridges. The China-proposed route from Xinjiang through Kyrgyzstan bypasses the North to link with Uzbekistan. China is reluctant to construct the Kyrgyzstan-proposed route, advocating a detour to bring its remote northern regions on the route, in part due to the longstanding dispute between Kyrgyzstan and Uzbekistan and also because it raises the cost by at least $\$ 1.5$ billion, enhancing suspicion in Kyrgyzstan of China's altruistic commitment to development for all.

The Imomali Rahmon regime has also pinned high hopes on China's infrastructural investments to transform Tajikistan into a critical transit passage between China and the Central Asian states. China has already heavily invested in Tajikistan's hydropower sector, power engineering, cement and manufacturing goods as well as farming from cotton to vegetable cultivation. Its accumulated direct investments in Tajikistan's economy reached $\$ 1.1$ billion in October 2016, which was nearly 30 percent of the total amount of the accumulated direct investments (Asia-Plus 2017), making it the largest investor in its economy, relegating Russia to a second place. 
Chinese investments have focused on developing medium-capacity hydroelectric power stations whereas the largest power stations remain under the control of Russia (Ferghana News 2017). Its major strategic object, the Rogun Hydropower Plant, needs an estimated $\$ 4$ billion of refurbishments (BBC News 2013). As Russia has been unable to put in the required investments, Rahmon announced the beginning of the construction of the world's tallest dam in Rogun in late 2018, indirectly appealing for China's investment, and for Russia's cooperation with China on the plant.

At the first glance, Chinese financing targeted to fill the infrastructural gaps in the Central Asian region portrays development in benign apolitical terms as beneficial to all. Central Asian elites have responded with celebratory affirmations of friendships of nations and peoples, expanding strategic partnership and expectations of mutual gains promised by the "win-win" scenario. Furthermore, the apparent absence of conditionality means a quick delivery of investment and aid without any public discussion and involvement of various non-state stakeholders, which could delay, or block the launching of projects.

In reality, the flow of investments from China, without discussion of a repayment schedule or the capacity of the target states to absorb aid has led to a rapid rise in the external debts of both Tajikistan and Kyrgyzstan. Tajikistan was already the largest recipient of aid of SCO receiving $\$ 600$ million out of $\$ 900$ million developmental aid to SCO states, though confusion has reigned on whether they were SCO or bilateral loans. Tajikistan's debt to China at $\$ 2.3$ billion is over half of its foreign debt (Chorshanbiyev 2017). China is also the largest lender to Kyrgyzstan, whose debt of $\$ 1.4$ billion to China's Exim Bank accounts for almost 40 per cent of its external public debt of $\$ 3.76$ billion (Business World 2016).

Finally, not all major China-proposed projects have proven to be realizable, others have been indefinitely postponed, casting doubts on China's commitment to carry out projects which appear to be less economically beneficial to China but could be game-changes for the involved Central Asian states. The much-celebrated construction of one of the branches of the China-Central Asia Gas Pipelines - "Line D"- running from Turkmenistan, Uzbekistan through Kyrgyzstan and Tajikistan to China, which would have enabled both Tajikistan and Kyrgyzstan to collect millions of dollars in transit fees annually, has been indefinitely postponed after several delays. The fall in global energy prices, China's present energy surplus, and its lowered economic growth rates are cited as the key reasons (Lelyveld 2017).

\section{The Securitization of China's Investments in Central Asia}

China has postulated a clear connection between economic backwardness, lack of connectivity and conflicts caused by disaffected groups prone to radicalization. ${ }^{6}$ The CCP leadership attributes the "three evil forces" (separatism, terrorism and religious extremism) in the Xinjiang Uyghur Autonomous Region to its isolation and lack of economic modernization (Kerr and Swinton 2008). China has poured in massive investments in transport and trade infrastructure in its restive regions for boosting modernization and

\footnotetext{
${ }^{6}$ The remote and landlocked Xinjiang Uyghur Autonomous region in Western China bordering the Central Asian region has been amongst China's most underdeveloped provinces. The Uyghurs had constituted a majority in the region until 2010, and together with ethnic Kazakhs constitute Turkophone Muslim groups distinct from Han Chinese (NBS 2013). The East Turkistan Independence movement, which gained momentum after the independence of the Central Asian Republics, garners support from kinship-based links with Uyghurs in neighbouring Kazakhstan, Kyrgyzstan, Tajikistan, Pakistan, as well as in Turkey.
} 
development which are seen as cornerstones of security. Zhu Rongji's "Develop the West" initiative, launched in the early 2000s, also saw cooperation with the neighbouring countries in Central Asia on border security critical to the securitization of Xinjiang. The international cooperation offered by China to the US-led Global War on Terror in post 9/11 context was an extension of its domestic concerns, which also established the "strategic triangle" of security cooperation between the US, Russia and China (Cooley 2012).

Within the framework of the SCO, all member states have pledged support to combating the three evil forces and signed bilateral agreements extraditing Uyghur separatists who China terms "terrorists". Kazakhstan has extradited alleged Uyghur separatists to China amidst widespread condemnation by domestic and international human rights groups (Windsor 2012). From its initial focus on securitization of borders, prevention of cross-border support to separatist groups and enhancing security cooperation based on recognition of the principle of sovereignty and non-interference in internal affairs of member states, SCO has grown into a regional security structure extending security cooperation to the US (particularly after 9/11) War against terror, establishing the RATS in 2004 to combat illicit cross-border drug trade and strengthen the US-led anti-terrorism measures.

With its enlargement in 2017 to include India and Pakistan, SCO is likely to shift its focus to inter-regional security issues connected with combating cross-border terrorism and the spread of radical Islam. The complex China-India relationship, traditional rivalry between India and Pakistan, and India's concerns over the CPEC which passes through some of the disputed lands on its border with Pakistan, have raised many questions about SCO's future role, effectiveness, cohesion and leadership. China has denied any ambition to turn SCO into a military bloc, reiterating its policy which is commonly described as "No alliance, No confrontation and No interference," founded on their foreign policy maxim "Five Principles of Peaceful Coexistence", which have also become the cornerstones of the SCO (MOFA 2004).

The BRI/SREB envisions transport and trade connections with Central and South Asia as critical to extending the arc of security further westward to establish a stable trade and transport passage to Europe. China's security engagement in the Central Asian region through bilateral agreements and multilateral regional structures is inevitable given its rising economic, political and ideological impact. The realization of security-oriented economic development across the region is paradoxically widening further its security activities and political role. The concerns for safeguarding the strategic investments - pipelines, electricity grids, factories, construction objects - together with the safety of its personnel against Islambased insurgency and local conflicts have led China to wield political influence in security provisions. Its state corporations and other commercial structures are beginning to assume a pro-active role in establishing a stable and secure climate in order to ensure better returns. In case of a dissonance between the protection of its economic investments for accruing profits and security objectives, China has tended to prioritize the latter.

China's major investments in Tajikistan and interests in Afghanistan's resources (Rashid 2017) and its stability have propelled it to securitize the $1344 \mathrm{~km}$ unmarked border between the two states which is used by drug smugglers, Islamic insurgents and other criminal groupings as hideout and passage for illicit trade. The China-built Gulhan post occupies a very strategic location on the top of a hill providing a clear view of the borders in one of the most inaccessible segments (Shahbazov 2017). The building of four further border check posts and a military training centre for security of its business and personnel also frees China 
from paying taxes, custom duties and other payments connected with the construction. In another agreement with the Tajik National Security Committee, China is providing for the construction of eleven outposts and a training center for border guards.

China's securitization overtures have so far supplemented Russian initiatives and strengthened security provision in the region (Nasar and Haand 2016). Its security involvement in Afghanistan, which is also a candidate member of the SCO, includes support of a development programme, ${ }^{7}$ joint bilateral military exercises with Tajikistan, with a small mobile Chinese contingent on the Afghanistan border and $\$ 70$ million in military aid to Afghanistan to safeguard the border, combat Taliban-affiliated Islamists and insurgents (Putz 2016). During his visit to Afghanistan in March 2016, Fang Fenghui, Chief of the People's Liberation Army, proposed a new Quadrilateral Cooperation and Coordination Mechanism alliance consisting of Afghanistan, China, Pakistan and Tajikistan to establish "cooperation in counterterrorism situation evaluation, clue verification, intelligence sharing, counterterrorism capacity building, counterterrorism joint training exercises and personnel training" (DW 2017). The labelling of China's initiatives as proposal for a "Central Asian military alliance" (Kucera 2016) may be premature and inaccurate as it complements earlier proposals by Russia to set up a "NATO-style joint task force" of post-Soviet states to secure Central Asia's borders (AFP 2015). China's involvement in the remote region could be a prelude to more substantive security arrangements in future given its $\$ 60$ billion investments in CPEC whose success also rests on stability in Afghanistan.

China has mobilized several People's Liberation Army (PLA) forces in 2016 to safeguard several coal, hydro, wind and solar power projects of CPEC and sought a firm commitment by the Pakistan army to protect its strategic interests (Defence Tube 2017). Following reports of China opening up its first naval base in Djibouti, speculation is rife on its next plan to expand its marine corps and for stationing new marine brigades in Gwadar (Chan 2017). While China's evolving security overtures in Central Asia are linked to its broader drive to securitize Xinjiang, connecting it both with Central Asia and onwards to Europe, as well as to South Asia and onwards through the Gwadar port to link it with its Maritime Silk Road, also lead it to acquire a more extensive military role, independent of its priorities in Xinjiang

China's security cooperation with Central Asia has so far concentrated on 'soft' objectives training, construction of facilities, military aid and joint exercises, particularly under the auspices of the SCO Peace Mission. Though China has denied interest in forming any military alliance, its emphasis on strengthening the capacity of the Central Asian states' military capabilities and "anti-terror" activities also resonate with the measures by the ruling elites on strengthening hard military capabilities and surveillance mechanisms. They also challenge the emphasis by the OSCE on the importance of human security through training to border officers border officers in Tajikistan and Kyrgyzstan on human skills and governance (OSCE 2017).

\section{Elite management of Popular anxieties}

China's investments and development assistance, as also noted in Africa (Brautigam 2011), are widely seen as accompanied by an import of Chinese technology, products, technical experts, managerial staff and labour force, along with Chinese business practices and

${ }^{7}$ China is a major stakeholder in Afghanistan's stabilization and development alongside the US, Russia and India. 
management style to ensure firm Chinese control over projects, benefits etc. The ruling elites in Central Asia, who are bolstered by Chinese economic and political support, have implicitly accepted these realities. Although they do not face legal-institutional or media pressures to divulge sensitive details, they face populist pressure of assuring their citizens that Chinese investments are working for the economic development of the nation and dispel anxieties about China's 'creeping expansion' and 'voracious appetite' for energy and natural resources in the region, which have fueled anti-Chinese sentiments.

Protests have erupted in several China-controlled factories and construction sites against China's reported resistance to use local workforce, offer competitive wages and acceptable work conditions, and against the environmental impact of Chinese enterprises (Lelik 2016). While the Central Asian regimes have so far managed to contain such protests, there is a tendency for nationalist sentiments to fuse with Sinophobia. ${ }^{8}$

Land in particular is a highly controversial issue. The reality, or the perception of it being leased to the Chinese, readily stirs nationalist sentiments, accusing their national elites of 'selling out' to the Chinese. Sporadic protests against the reported lease of lands to Chinese for agricultural or commercial use have frequently broken out in Kazakhstan and Kyrgyzstan. At the same time, the prospects of leasing lands to Chinese who bring the requisite technology, seeds, fertilisers along with a higher level of skills for intensive farming leading to higher yields are very attractive to the Central Asian states (Hofman 2016).

The level of popular sensitivities on the issue and the scale of previous mobilizations have constrained Kyrgyzstan's ruling elites in concluding any future land-lease agreement with China and ceding control over the country's precious resources - gold, hydroelectric power without making the terms and conditions transparent (Lewis 2008, RFE/RL 2013). In Kazakhstan the scale of protests in summer 2016 against the proposed law for extending the lease of agricultural land to foreigners from 10 to 25 years took the state authorities by surprise. ${ }^{9}$ Nazarbaev was forced to accede to public pressure by issuing a moratorium on the proposed law; it is unlikely that a law on leasing land to China for agricultural, industrial or commercial purposes will be debated in the near future.

However, Kazakhstan's resource potential, economic strength and crucial transit location enable it to better manage popular expectations and relations with Eurasian Economic Union (EEU), China and Russia. Kyrgyzstan is juggling between Russia's military aid, the uncertain economic effects emanating from its membership in 2015 in the EEU, and its growing dependence on Chinese investments. Its new president Sooronbay Jeenbekov will need to manouevre between economic dependence on China, China's pressures on Kyrgyzstan to combat the rise of Islamic militancy and popular anti-China mobilizations by nationalists. Finally, Tajikistan, dependent on Russia for security and economic assistance and on China for infrastructural financing, may become vulnerable to its rising debt to China and political compromises resulting from China's anticipated writing off of its debt (Eurasia News 2016).

\footnotetext{
${ }^{8}$ In their analysis of perceptions of China in Kazakhstani media Burkhanov and Chen (2016) note that Kazakh language press, which has a wider readership in rural regions, tends to reveal much greater levels of Sinophobia as it propounds nationalist sentiments. Similarly, the numerous anti-China mobilizations in Kyrgyzstan have occurred in rural settings, mobilised by nationalist opposition leaders.

${ }^{9}$ The proposed land reform bill was an attempt to introduce much needed changes to the 2003 Land Code, with many complex features, but it was presented by protestors as being designed to enable the Chinese to acquire a long-term control over Kazakhstan's land.
} 
In contrast to Kazakhstan and Kyrgyzstan, Tajikistan's decision to lease one percent of its arable land to China in 2011 sparked little debate, attesting to its lack of leverage over relations with China. The sizable increase in Chinese investments in Tajikistan since Dushanbe agreed to hand over around one percent of its territory to Beijing in exchange for having some of its debts forgiven (Bustonkala 2011) reinforced the view that the land lease was an informal condition to secure Chinese investments in infrastructural projects.

To conclude, Chinese investments hold considerable attraction for the incumbent leaders as they prioritize economic development over political reforms and resonate with notions of stability, state-led economic development than economic competition and democratic norms upheld by Europe. At the same time, the growing external debt of Tajikistan and Kyrgyzstan, as well as of Pakistan where China has invested over $\$ 60$ billion - 20\% of Pakistan's GDP in CPEC, are raising questions about national sovereignty of these states and their capacity to absorb aid and investment. It also raises concerns that China may write off this debt for political concessions and enhanced strategic leverage (Javed 2017).

These developments will have impact on European involvement in Central Asia given that European institutions are second largest donors to the region after China. This has led to calls for complementarity and cooperation in economic and security matters between China and Europe within the framework of the SREB: already, European Bank of Reconstruction and Development (EBRD) has begun cooperation with AIIB in Tajikistan (EBRD 2016[a]).

\section{Conclusion}

This article has examined the nature of Chinese investments in Central Asia and the responses these have elicited from the Central Asian states. Whilst the SREB had mixed responses in Western media - with many debating whether it was a new drive by China to turn its commercial power into political and security leverage by gradually easing into Russia's traditional sphere of influence - the responses in Russia and Central Asia have been enthusiastic (Le Corre 2017, DW 2017). After welcoming the SREB as a chance to "catch the Chinese wind in the sails of the Russian economy" (Karaganov 2014) Putin has actively sought to forge a close multilateral partnership between the EEU (includes Russia, Belarus, Kazakhstan, Kyrgyzstan, Belarus, and Armenia) and the BRI/SREB, culminating in Putin and Xi signing an Agreement (May 2015) that aligns the BRI and the EEU.

$\mathrm{Xi}$ 's assurances such as "we do not seek to dominate regional affairs or establish any sphere of influence. We stand ready to enhance communication and coordination with Russia and all Central Asian countries to strive to build a region of harmony" have boosted confidence amongst leadership circles in Russia and Central Asia (Xi 2013). However, Xi's pronouncements on commitment to peaceful development and the independent foreign policy have been directed at its Silk Road neighbours and not at Europe. This explains the lukewarm European responses to the SREB and the guarded reception from the EU, which also reflect the pressures from industrial lobbies in Germany and France (EP 2016, Interviews, Brussels, Berlin 2017).

While Russia and China strengthen their strategic partnership and forge a cooperation agreement between SREB and the EEU, the EU and European institutions face the challenges of retaining their niche and a coherent strategy in the region in the face of lack of leadership by the US. The developmental promise of the BRI and attraction of Chinese investments are not unique to Central Asia, they are also deepening divisions within Europe, exacerbated by 
Chinese BRI policy of " $16+1$ " which overlook European demarcations of EU and non-EU. Chinese financing is more attractive to transport and energy infrastructure projects in southeastern European states awaiting accession to EU, cash-strapped Greece (Piraeus) and Hungary (Belgrade-Budapest Railway). Chinese investments through the BRI are further undermining the consensus-based approach of EU with Greece blocking the EU statement on China's Human Rights in the UN July 2017, highlighting the emerging divisions in Europe.

As we have argued, the BRI combines material and ideational elements backed by Chinese financial and cultural institutions. This has led to its perception in the EU as "[putting] a Chinese stamp on world and impose a Chinese system, a real global system but not like ours, based on human rights and individual liberties" (German Foreign Minister Sigmar Gabriel cited in Erlanger 2018). As China's global stature, propped up further by the extension of $\mathrm{Xi}$ 's tenure by another decade, is accompanied by the rapid expansion of Chinese soft power and the ability to set alternative norms, the EU needs to meet the challenge of developing a strategic coherence to reinforce its status as a normative power in Central Asia. Moreover, the diverse range of responses to the SREB in Central Asian states, the medium and long term implications of China-Central Asia partnership in the SREB and the close Sino-Russian bilateral cooperation, including the cooperation between SREB and EEU all have several important and wide-ranging implications for Europe. These need to be factored in to refine the EU's strategy towards the region and engage comprehensively with China though bilateral and multilateral channels in order to strengthen its own normative security building vision in the Eurasian region.

There are hopeful signs of new avenues of economic partnership between Europe and China evolving as the AIIB emerges as the largest investor in the region, giving a new direction to projects traditionally funded by the $\mathrm{ADB}$, European institutions are turning to form partnerships with the AIIB. For instance, the AIIB and the EBRD are co-financing a \$105.9 million project to rebuild a $5 \mathrm{~km}$ section of road connecting Dushanbe to the Uzbek border, part of the Dushanbe-Uzbekistan road improvement project (AIIB 2016). In what originally was an EBRD- ADB project, with the two institutions funding phase one of the Tajik road project (EBRD 2012), AIIB has stepped in to jointly fund phase two of the Tajik Road project with EBRD (EBRD 2016 [b]). While a partnership between China and Europe in the economic realm is emerging in the region, features of Chinese financing examined above also alert us that this partnership is founded not on shared principles, but on common objectives, albeit espousing contrary values.

This makes it incumbent on the EU to define its own strategy towards Central Asia in light of China's expanding economic impact and evolving political and security engagement, and identify key areas of compatibility and cooperation. Some of these are: security in Afghanistan, partnership with AIIB in building infrastructure and supplementing these with the soft infrastructure and technical expertise in which EU still retains its niche, working to improve governance and capacity for absorbing aid in which EU institutions have aided important development programmes.

EU has been an influential normative actor centred on building of democratic institutions, civil society, human rights with a strong emphasis on education, scientific-technical expertise and development human development. Despite differences in ideological and normative agenda, areas of cooperation and complementarity could be identified. China's prowess in building hard transport and trade infrastructure can be reinforced through Europe's reputation 
in scientific-intellectual training, service provision and soft infrastructure (Ghiasy and Zhou 2017) for sustainability and long-term stability.

\section{Reference list}

AFP (2015) Putin warns of spillover from Afghanistan fighting. The Express Tribune. https://tribune.com.pk/story/974021/putin-warns-of-spillover-from-afghanistan-fighting/. Accessed on 12 January 2018

AIIB (2016) Asia for the Future, Annual Report and Accounts 2016. AIIB. https://www.aiib.org/en/news-events/news/2016/annualreport/.content/download/Annual_Report_2016.pdf. Accessed on 20 January 2018

Asia Development Bank [ADB] (2012) Public Private Partnerships Key to Meeting Asia’s \$8 Trillion Infrastructure Needs - Study. ADB. http://www.adb.org/news/public-privatepartnerships-key-meeting-asias-8-trillion-infrastructure-needs-study. Accessed on 12 January 2018

Asia-Plus (2017) China leads in direct investment in Tajikistan's economy. Asia-Plus. https://www.news.tj/en/news/tajikistan/economic/20170203/236278. Accessed on 12 January 2018

BBC (2013) Tajikistan's Rogun: Building the world's tallest dam. BBC News. http://www.bbc.com/news/world-asia-37929367. Accessed on 12 January 2018

Brautigam D (2011) The Dragon's Gift: The Real Story of China in Africa. Oxford University Press, USA

Burkhanov A and Chen Y (2016) Kazakh perspective on China, the Chinese, and Chinese migration. Ethnic and Racial Studies. 39,12:2129-2148.

Business World (2016) Kyrgyzstan: Debts to China the worst. Business World. https://smiraponitke.com/02/12/2016/kyrgyzstan-debts-to-china-the-worst.html. Accessed on 19 January 2018

Bustonkala R K (2011) Tajik land deal extends China's reach in Central Asia. Reuters. https://www.reuters.com/article/us-tajikistan-china-land/tajik-land-deal-extends-chinasreach-in-central-asia-idUSTRE72O1RP20110325. Accessed on 19 January 2018

Callahan W A (2016) China 2035: from the China Dream to the World Dream, Global Affairs, 2:3, 247-258.

Chikanaev S (2017) Kazakhstan: 'pryzhka' Poyasa- puti (kontseptsiia Odin poyas - Odin Put) [Kazakhstan: 'Buckle' in Belt and Road (The Concept of One Belt- One Road)]. GRATA International.

Chan M (2017) As overseas ambitions expand, China plans 400 per cent increase to marine corps numbers, sources say. South China Morning Post. 
http://www.scmp.com/news/china/diplomacy-defence/article/2078245/overseas-ambitionsexpand-china-plans-400pc-increase. Accessed on 12 January 2018

Chorshanbiyev P (2017) Tajikistan's foreign debt nears 2.3 billion U.S. dollars. Asia-Plus. https://www.news.tj/en/news/tajikistan/economic/20170524/240186Accessed on 19 January 2018

Clarke, M (2013) China's Strategy in "Greater Central Asia: Is Afghanistan the Missing Link? Asian Affairs: An American Review 20:1, 1-19.

Cooley A (2012) Great Games, Local Rules: The New Great Power Contest in Central Asia. Oxford University Press, New York

Defence Tube (2017) China wants Pakistan Army to take over CPEC projects. https://www.youtube.com/watch?v=YlbigS4SPfc. Accessed on 12 January 2018

DW (2017) 'New Silk Road and China's hegemonic ambitions. DW. http://www.dw.com/en/new-silk-road-and-chinas-hegemonic-ambitions/a-38843212. Accessed on 20 January 2018

EBRD (2012) Key link in the road from Tajikistan to the world. http://www.ebrd.com/news/2012/key-link-in-the-road-from-tajikistan-to-the-world.html. Accessed on 22 January 2018

EBRD (2016 [a]) Road project in Tajikistan becomes first joint EBRD-AIIB investment. http://www.ebrd.com/news/2016/road-project-in-tajikistan-becomes-first-joint-ebrdaiibinvestment.html. Accessed on 19 January 2018

EBRD (2016 [b]) Road safety for key thoroughfare of Dushanbe, Tajikistan. http://www.ebrd.com/news/2016/road-safety-for-key-thoroughfare-of-dushanbetajikistan.html. Accessed on 22 January 2018

EP (2016) Briefing: One Belt One Road - China's Regional Integration Initiative. http://www.europarl.europa.eu/thinktank/en/document.html?reference=EPRS_BRI(2016)586 608. Accessed on 1 March 2018.

Erlanger, S (2018) Europe Once Saw Xi Jinping as a Hedge Against Trump. Not Anymore. https://www.nytimes.com/2018/03/04/world/europe/europe-china-xi-trump-trade.html\#storycontinues-2 Accessed on 1 March 2018

Eurasianet (2015) Kyrgyzstan Hails Epoch-Making Power Line. Eurasianet. https://eurasianet.org/node/74876. Accessed on 19 January 2018.

Eurasia News (2016) Tajikistan is turning into the new Province of China. Eurasia News. http://eurasianews.info/en/analytics/tajikistan-is-turning-into-the-new-province-of-china2.html. Accessed on 22 January 2018

Ferghana News (2017) Emomali Rahmon asks China to participate more actively in construction of medium hydro power stations in Tajikistan. Ferghana News. 
http://enews.fergananews.com/news.php?id=3458\&mode=snews. Accessed on 12 January 2018

Ghiasy, R and Zhou, J (2017) The Silk Road Economic Belt. Considering security implications and EU-China cooperation prospects. SIPRI/Friedrich-Ebert-Stiftung, Stockholm. https://www.sipri.org/publications/2017/other-publications/silk-road-economicbelt. Accessed on 27 February 2018.

Hofman I (2016) Politics or profits along the 'Silk Road': what drives Chinese farms in Tajikistan and helps them thrive? Eurasian Geography and Economics. 57,3,457:481.

Hussain K (2017) CPEC Masterplan Revealed. Dawn.

https://www.dawn.com/news/1333101. Accessed on 12 January 2018

Javed S H (2017) CPEC could develop into Pakistan's debt trap. The Express Tribune. https://tribune.com.pk/story/1580950/2-cpec-develop-pakistans-debt-trap/. Accessed on 19 January 2018

Karaganov S (2014) Is Russia turning East? Valdai Club.

http://valdaiclub.com/a/highlights/is_russia_turning_east/. Accessed on 20 January 2018

Kerr D (2010) Strategic Regionalism: Central Asian and Russian Perspectives on China's Reemergence. International Affairs. 86,1:127-152. Doi: 10.1111/j1468-2346.2010.00872.x

Kerr D and Swinton L C (2008) China, Xinjiang and the Transnational Security of Central Asia. Critical Asian Studies. 40:89-112.

Kobayashi Y and Sanchez A (2017) Minilateralism à la Chine. Lau China Institute Policy Paper Series. 1, 6:2-17. https://www.kcl.ac.uk/sspp/departments/lci/documents/policypapers/Kobayashi-Sanchez-Final-policy-brief-17-August-2017.pdf. Accessed on 12 January 2018

Kucera J (2016) China proposes New Central Asian military alliance. Eurasianet. http://www.eurasianet.org/node/77896. Accessed on 12 January 2018

Le Corre P (2017) Europe's mixed views on China's One Belt, One Road initiative. Brookings. https://www.brookings.edu/blog/order-from-chaos/2017/05/23/europes-mixedviews-on-chinas-one-belt-one-road-initiative/. Accessed on 20 January 2018

Lelik A (2016) Kyrgyzstan: Bishkek Hopes Chinese Investment Can Produce Industrial Breakthrough. Eurasianet. https://eurasianet.org/node/79346. Accessed on 19 January 2018

Lelyveld M (2017) China Shelves Central Asia Gas Plan. Radio Free Asia. http://www.rfa.org/english/commentaries/energy_watch/china-shelves-central-asia-gas-plan03202017103720.html. Accessed on 12 January 2018

Lewis D (2008) The dynamics of regime change: Domestic and international factors in the 'Tulip Revolution'. Central Asian Survey 27,3-4,265-277 
Millward J (2009) Positioning Xinjiang in Eurasian and Chinese History: Differing Visions of the 'Silk Road'. In Clarke M and Mackerras C (eds). China, Xinjiang and Central Asia: History, Transition and Future Prospects into the 21st Century. Routledge, London, 55-74

The Ministry of Foreign Affairs of the People's Republic of China [MOFA] (2004) The Five Principles of Peaceful Coexistence. Ministry of Foreign Affairs.

http://www.fmprc.gov.cn/mfa_eng/topics_665678/seminaronfiveprinciples_665898/t140589. shtml. Accessed on 19 January 2018

Nasar I and Haand J (2016) Afghanistan Welcomes Chinese Anti-terror Proposal. Voice of America. https://www.voanews.com/a/afghanistan-welcomes-chinese-anti-terrorproposal/3215160.html. Accessed on 12 January 2018

National Bureau of Statistics of China [NBS] (2013) 2010 Population Census. National Bureau of Statistics of China. http://www.stats.gov.cn/english/statisticaldata/censusdata/ Accessed on 12 January 2018

National Development and Reform Commission [NDRC] (2015) Vision and Actions on Jointly Building Silk Road Economic Belt and 21st-Century Maritime Silk Road. National Development and Reform Commission.

http://en.ndrc.gov.cn/newsrelease/201503/t20150330_669367.html. Accessed on 12 January 2018

OSCE (2017) OSCE conducts training of trainers for border officers of Tajikistan and Kyrgyzstan. http://www.osce.org/office-in-tajikistan/319711. Accessed on 12 January 2018

Putz C (2015) Kyrgyzstan Declares Energy Independence. The Diplomat. https://thediplomat.com/2015/09/kyrgyzstan-declares-energy-independence/. Accessed on 12 January 2018

Putz C (2016) China in Central Asia: Building Border Posts in Tajikistan. The Diplomat. https://thediplomat.com/2016/09/china-in-central-asia-building-border-posts-in-tajikistan/. Accessed on 12 January 2018

Rashid A (2017) The stakes are high for China in Pakistan and Afghanistan. The Financial Times. https://www.ft.com/content/3a779394-66e5-11e7-9a66-93fb352ba1fe. Accessed on 20 January 2018

RFE/RL (2013) Chinese Mining Company Operations in Kyrgyzstan Blocked By Protesters. Radio Free Europe Radio Liberty. https://www.rferl.org/a/chinese-mining-companyoperations-kyrgyzstan-blocked-protesters/24987866.html. Accessed on 20 January 2018

Shahbazov F (2017) China's Long March into Central Asia: How Beijing Expands Military Influence in Tajikistan. The Central Asia-Caucasus Analyst.

https://cacianalyst.org/publications/analytical-articles/item/13429-china\%E2\%80\%99s-longmarch-into-central-asia-how-beijing-expands-military-influence-in-tajikistan.html. Accessed on 20 January 2018 
SPIEF [St Petersburg International Economic Forum] 2017: From Wider Europe to a Big Eurasian Partnership? (2017) Eurasian Studies: Higher School of Economics, Russia. http://greater-europe.org/archives/2955. Accessed on 28 February 2018.

Starr, S F (2005) A 'Greater Central Asia Partnership' for Afghanistan and Its Neighbors. Central Asia-Caucasus Institute \& Silk Road Studies Programme, Johns Hopkins University.

State Information Council [SIC] (2017) Big Data Report of Trade Cooperation Under the Belt and Road Initiative. State Information Council. https://www.yidaiyilu.gov.cn/wcm.files/upload/CMSydylgw/201703/201703241243039.pdf. Accessed on 22 January 2018

Tengri News (2013) Share of China's companies in Kazakhstan's oil production estimated at 24\%. Tengri News. https://en.tengrinews.kz/markets/Share-of-Chinas-companies-inKazakhstans-oil-production-24323/. Accessed on 19 January 2018

Windsor M (2012) Case Watch: UN Holds Kazakhstan Accountable in Uighur Extradition Case. Open Society Foundation. https://www.opensocietyfoundations.org/voices/case-watchun-holds-kazakhstan-accountable-uighur-extradition-case. Accessed on 19 January 2018

Xi J (2013) Promote Friendship Between Our People and Work Together to Build a Bright Future. Ministry of Foreign Affairs.

http://www.fmprc.gov.cn/mfa_eng/wjdt_665385/zyjh_665391/t1078088.shtml. Accessed on 19 January 2018

Xi J (2014) The Governance of China. Foreign Languages Press, Beijing

Xi J (2016) Full Text of Address by President Xi Jinping of China at the Inauguration Ceremony of the Asian Infrastructure Investment Bank. Xinhua. http://news.xinhuanet.com/english/china/2016-01/16/c_135015661.htm. Accessed on 12 January 2018

Zhao H (2007) Central Asia in China's Diplomacy. In Rummer E, et. Al (ed). Central Asia: Views from Washington, Moscow and Beijing. ME Sharpe, Armonk New York, pp. 137-214 